\title{
STUDI PERKEMBANGAN PERUMAHAN DAN PENYEDIAAN FASILITAS DI CITRA RAYA
}

\author{
Fredrick Effendy ${ }^{1)}$, Liong Ju Tjung ${ }^{2)}$, Sylvie Wirawati ${ }^{4)}$
}

\author{
1)Program Studi S1 PWK, Fakultas Teknik, Universitas Tarumanagara, fredrickdidik@gmail.com \\ 2)Program Studi S1 PWK, Fakultas Teknik, Universitas Tarumanagara, liongjutjung@gmail.com \\ 3)Program Studi S1 PWK, Fakultas Teknik, Universitas Tarumanagara, sylvie.wirawati@gmail.com
}

\begin{abstract}
Abstrak
Citra Raya merupakan salah satu kota baru yang berada di Kabupaten Tangerang, Banten, yang telah dikembangkan sejak tahun 1994. Proyek terbesar Ciputra Group ini berdiri di atas lahan seluas 2.760 hektar. Perkembangan Citra Raya begitu pesat, luas lahan yang telah dikembangkan mencapai 1.000 hektar. Saat ini Citra Raya memiliki 51 cluster perumahan, termasuk EcoHome yang merupakan produk apartemen pertama. Citra Raya terus menghadirkan beragam fasilitas terbaru untuk memenuhi kebutuhan penghuninya. Fasilitas yang dibangun juga terus bertambah skala pelayanannya seiring dengan berkembangnya Citra Raya. Penelitian ini bertujuan untuk mengetahui kronologi / timeline perkembangan perumahan dan fasilitas di Citra Raya, mengetahui ketercukupan jumlah fasilitas yang terbangun di Citra Raya terhadap standar kebutuhan fasilitas, dan mengetahui hubungan antara perkembangan perumahan dan penyediaan fasilitas di Citra Raya. Pengumpulan data dalam penelitian ini dilakukan dengan cara survei lapangan, wawancara dengan pengembang, media elektronik, serta studi pustaka. Lalu terdapat lima analisis yang dilakukan, yaitu analisis perkembangan Citra Raya, analisis perkembangan perumahan, analisis penyediaan fasilitas, analisis ketercukupan fasilitas, dan analisis hubungan perkembangan perumahan dan fasilitas. Berdasarkan hasil penelitian diketahui bahwa fasilitas yang ada di Citra Raya telah mencukupi kebutuhan penghuni di dalamnya. Meskipun beberapa fasilitas masih kurang dari segi jumlahnya, namun jika dilihat dari luas lahan yang terbangun telah memenuhi standar yang ada. Lalu perkembangan hunian dan penyediaan fasilitas di Citra Raya memiliki hubungan yang kuat positif. Bertambahnya jumlah hunian juga diikuti dengan bertambahnya jumlah fasilitas.
\end{abstract}

\section{Kata kunci: fasilitas; perkembangan; perumahan}

\begin{abstract}
Citra Raya is one of the new town in the Regency of Tangerang, Banten, which has been developed since 1994. This is the largest project of the Ciputra Group that stands on an area of 2,760 hectares. The development of Citra Raya is so rapid, the area of land that has been developed reaches 1,000 hectares. Currently Citra Raya has 51 residential clusters, including EcoHome which is the first apartment product. Citra Raya continues to present a variety of the latest facilities to meet the needs of its residents. The built facilities also continue to increase in scale as the services of Citra Raya develop. The purpose of this study is to determine the chronology / timeline of the development of housing and facilities in Citra Raya, determine the adequacy of the number of facilities built in Citra Raya to the standard needs of facilities, and knowing the relationship between housing development and the provision of facilities in Citra Raya. Data collection in this research was carried out by field surveys, interviews with developers, electronic media, and literature studies. Then there are five analyzes carried out, namely analysis of the development of Citra Raya, analysis of housing development, analysis of facility provision, analysis of facility adequacy, and analysis of the relationship between housing and facility development. Based on the results of the study note that the facilities in Citra Raya are sufficient for the residents in it. Even
\end{abstract}


though some of the facilities are still lacking in terms of numbers, when viewed from the area of land that has been developed it meets existing standards. Then the development of housing and provision of facilities in Citra Raya has a strong positive relationship. The increase in the number of houses was also followed by the increase in the number of facilities.

Keywords: development, facility, housing

\section{PENDAHULUAN}

Lahan di pusat kota sudah semakin terbatas dan mahal sehingga para developer mulai mengembangkan kawasan perumahan di pinggiran kota (periphery). Beberapa kawasan perumahan baru tersebut memiliki skala pembangunan yang besar sehingga bisa disebut juga sebagai sebuah kota baru atau kota mandiri. Sejak tahun 1980-an, para developer sudah mulai membangun kota baru yang tersebar di daerah Bogor, Depok, Tangerang, dan Bekasi. Salah satu kota baru tersebut adalah Citra Raya yang telah dikembangkan sejak tahun 1994. Ini merupakan proyek terbesar Ciputra Group yang berdiri di atas lahan seluas $2.760 \mathrm{Ha}$ dengan beragam tipe hunian dan komersial.

Citra Raya tumbuh begitu pesat, saat ini sudah ada 51 cluster perumahan dengan jumlah penghuni di dalamnya mencapai lebih dari 65 ribu jiwa. Menurut Kuswartojo (2010), penting bagi perumahan skala besar dapat memenuhi kebutuhan pelayanan penghuninya dengan dilengkapi prasarana, utilitas, fasilitas sosial, dan fasilitas umum yang memadai sesuai dengan jumlah penduduk yang ditampungnya. Kehadiran fasilitas yang beragam dan lengkap juga dapat menjadi daya tarik tersendiri bagi konsumen untuk membeli produk perumahan di suatu kota. Saat ini Citra Raya memiliki berbagai fasilitas, namun yang akan dibahas dalam penelitian ini dibatasi berupa fasilitas pendidikan, fasilitas peribadatan, fasilitas kesehatan, fasilitas komersial, dan fasilitas olahraga/ rekreasi.

Terdapat lima elemen pembentuk ruang kota menurut Sujarto (1995), yaitu wisma (lingkungan hunian), karya (tempat bekerja), marga (infrastruktur jalan), suka (tempat rekreasi), dan penyempurna (fasilitas perkotaan). Perumahan dan fasilitas merupakan dua dari lima elemen pembentuk kota yang saling terkait satu sama lain. Apabila ada penambahan perumahan maka harus diimbangi dengan penambahan fasilitas, begitu pula sebaliknya. Dengan menyediakan fasilitas yang lengkap, diharapkan penghuni di dalam kota baru tidak perlu pergi ke luar lagi untuk memenuhi kebutuhannya.

Rumusan masalah dalam penelitian ini ada dua. Pertama, jumlah perumahan yang terus bertambah diikuti dengan penambahan fasilitas penunjang untuk memenuhi kebutuhan penghuni. Lalu yang kedua, menurut Oentarto (2004), rata-rata penyediaan sarana dan prasarana perumahan di Indonesia hanya berdasarkan standar developer tanpa melihat standar pelayanan minimal yang ada. Berdasarkan permasalahan di atas, maka penulis ingin mengetahui perkembangan perumahan dan penyediaan fasilitas di Citra Raya.

Tujuan yang ingin dicapai dalam penelitian ini, yaitu mengetahui kronologi / timeline perkembangan perumahan dan fasilitas di Citra Raya dan mengetahui ketercukupan jumlah fasilitas yang terbangun di Citra Raya. Dalam menghitung ketercukupan jumlah fasilitas, penulis menggunakan dua standar untuk dibandingkan, yaitu SNI 03-1733-2004 dan Perda DKI Jakarta No.6 Tahun 1999. 


\section{KAJIAN LITELATUR}

\section{Kota Baru}

Ide mengenai kota baru pertama kali muncul sekitar awal abad ke-19 yang dilatar belakangi oleh kondisi sosial masyarakat yang memburuk dari perkembangan industri di zaman itu. Pelopor utama ide kota baru adalah Ebenezer Howard (1850-1928) melalui konsep Garden City. Menurut Perloff dan Sandbery (1973), kota baru adalah kota yang dirancang dan direncanakan untuk bisa mandiri dengan ukuran luas yang relatif kecil dalam komunitas yang seimbang. Kota baru tidak selalu dibangun di atas lahan yang masih kosong, tetapi juga mungkin merupakan pengembangan dan pembaharuan permukiman pedesaan atau kota kecil secara total menjadi kota lengkap yang mandiri (Golany, 1978 dalam Sujarto, 1993)

\section{Perumahan dan Permukiman}

Berdasarkan Undang-Undang No. 1 Tahun 2011 tentang Perumahan dan Kawasan Permukiman disebutkan bahwa perumahan adalah adalah kumpulan rumah sebagai bagian dari permukiman, baik perkotaan maupun perdesaan, yang dilengkapi dengan prasarana, sarana, dan utilitas umum sebagai hasil upaya pemenuhan rumah yang layak huni. Sedangkan permukiman adalah bagian dari lingkungan hunian yang dari terdiri atas lebih dari satu satuan perumahan yang mempunyai prasarana, sarana, utilitas umum, serta mempunyai penunjang kegiatan fungsi lain di kawasan perkotaan atau kawasan perdesaan. Terdapat beberapa faktor yang mempengaruhi permukiman dan perumahan yang dapat dilihat dari 9 aspek menurut Yudohusodo (1991), yaitu faktor geografi, faktor kependudukan, faktor Kelembagaan, faktor swadaya dan peran serta masyarakat, faktor sosial budaya, faktor ekonomi, faktor sarana dan prasarana, faktor pertahanan, serta faktor ilmu pengetahuan dan teknologi.

\section{Hunian Berimbang}

Hunian berimbang adalah perumahan atau kawasan permukiman yang dibangun secara berimbang dengan komposisi tertentu antara rumah mewah, rumah menengah, dan rumah sederhana. Hal ini bertujuan untuk mewujudkan perumahan dan kawasan permukiman yang sehat, aman, serasi, dan teratur dengan berbagai kelompok masyarakat dari berbagai profesi, tingkat ekonomi, dan status sosial serta menghindari terciptanya lingkungan perumahan eksklusif yang dapat mendorong terjadinya kerawanan dan kecemburuan sosial. Berdasarkan Surat Keputusan Bersama (SKB) Menteri Dalam Negeri, Menteri Pekerjaan Umum, dan Menteri Negara Perumahan Rakyat Nomor 648-384 Tahun 1992, Nomor 739/KPTS/1992, dan Nomor 09/KPTS/1992 tentang Pedoman Pembangunan Perumahan dan Permukiman dengan Lingkungan Hunian Berimbang bahwa komposisi antara rumah mewah, rumah menengah, dan rumah sederhana adalah $1: 3: 6$. Selanjutnya aturan ini direvisi atau diganti dengan Peraturan Menteri Perumahan Rakyat (Permenpera) Nomor 10 Tahun 2012 dengan perbandingan antara rumah mewah, rumah menengah, dan rumah sederhana adalah $1: 2: 3$.

\section{Fasilitas}

Fasilitas merupakan salah satu aspek yang mendasar dalam pembangunan suatu kota. Menurut Undang-Undang No. 1 Tahun 2011 tentang Perumahan dan Kawasan Permukiman, fasilitas sosial adalah fasilitas dalam lingkungan hunian yang berfungsi untuk mendukung penyelenggaraan dan pengembangan kehidupan sosial, budaya, dan ekonomi. Sedangkan fasilitas umum adalah kelengkapan dasar fisik lingkungan hunian yang memenuhi standar tertentu untuk kebutuhan tempat tinggal yang layak, sehat, aman, dan nyaman.

\section{Skala Pelayanan Fasilitas}

Fasilitas dapat dibagi menjadi lima jenis berdasarkan skala pelayanannya, yaitu:

a) Fasilitas tipe neighborhood, merupakan fasilitas yang memiliki skala pelayanan terkecil, yaitu untuk tingkat lingkungan perumahan atau kelurahan. 
b) Fasilitas tipe community, merupakan fasilitas yang memiliki skala pelayanan untuk tingkat komunitas atau kecamatan.

c) Fasilitas tipe regional, merupakan fasilitas yang memiliki skala pelayanan untuk tingkat kota atau kabupaten.

d) Fasilitas tipe super regional, merupakan fasilitas yang memiliki skala pelayanan untuk tingkat antar kota atau provinsi.

e) Fasilitas tipe internasional, merupakan fasilitas yang memiliki skala pelayanan untuk tingkat nasional hingga ke tingkat internasional.

\section{METODE}

Objek studi dalam penelitian ini adalah Citra Raya yang berlokasi di Kecamatan Cikupa dan Kecamatan Panongan, Kabupaten Tangerang, Provinsi Banten. Luas wilayah yang akan diteliti dibatasi sampai dengan lahan yang sudah dikembangkan hingga saat ini, yaitu seluas $1.000 \mathrm{Ha}$. Data dalam penelitian ini dikumpulkan dari berbagai sumber, yaitu survei lapangan untuk mengetahui kondisi eksisting, wawancara dengan pengembang untuk mengetahui profil dan perkembangan Citra Raya, lalu studi pustaka dan media elektronik untuk mengetahui perkembangan perumahan dan fasilitas. Metode analisis deskriptif digunakan untuk menjelaskan perkembangan Citra Raya, termasuk perumahan dan fasilitas yang ada di dalamnya. Metode analisis komparatif digunakan untuk membandingkan kondisi eksisting dari hunian dan fasilitas di Citra Raya dengan ketentuan/standar yang ada. Lalu metode analisis korelasi digunakan untuk menggambarkan hubungan antara perkembangan perumahan dan fasilitas di Citra Raya.

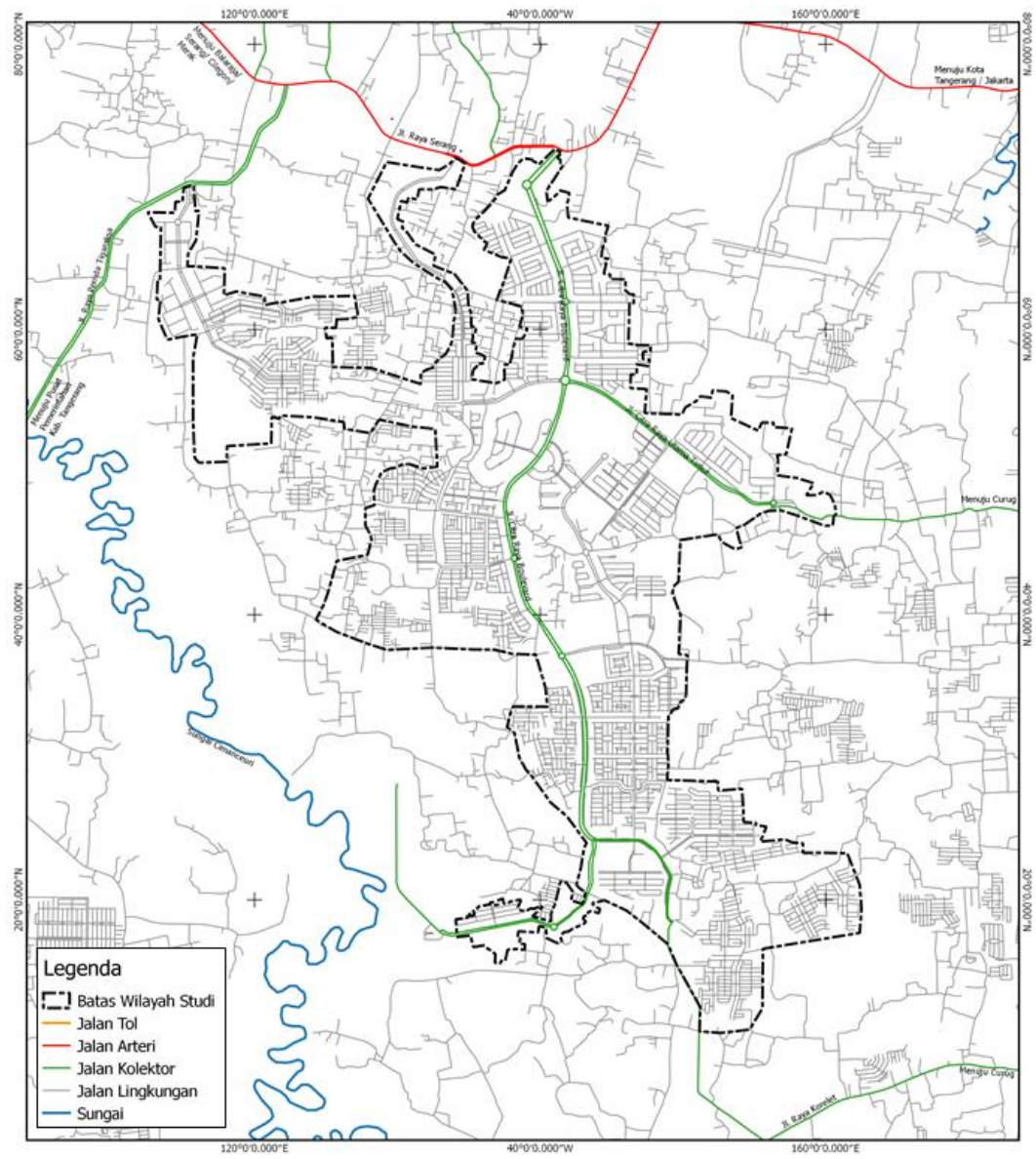

Gambar 1. Peta Batas Wilayah Studi

Sumber: Hasil Olahan Penulis, 2020 


\section{DISKUSI DAN HASIL}

\section{Profil Citra Raya}

Citra Raya merupakan sebuah kota baru yang dikembangkan oleh Ciputra Group di atas lahan seluas 2.760 hektar di Kabupaten Tangerang, Provinsi Banten. Citra Raya mulai dikembangkan sejak tahun 1994 yang di dalamnya terdapat beragam produk hunian, komersial, dan fasilitas penunjang. Pengembangan kawasan di Citra Raya menerapkan program EcoCulture sejak tahun 2011 untuk menghadirkan lingkungan yang nyaman dihuni.. Berkat pertumbuhannya yang sangat pesat, Citra Raya telah mencatatkan diri sebagai Regional and Business Center yang kuat di Tangerang. Lahan di Citra Raya yang telah dikembangkan sampai saat ini kurang lebih seluas 1.000 hektar.

Citra Raya merupakan the largest integrated township development yang dikembangkan oleh Ciputra Group. Proyek terbesar Ciputra Group ini memiliki gerbang masuk utama yang besar dan megah yang disebut sebagai icon of the region. Ikon ini sangat istimewa dan menjadi ciri khas karena dari 100 lebih proyek Ciputra Group, hanya ada 2 di Indonesia, salah satunya yaitu di Citra Raya, dan satu lagi di Citra Indah City. Di setiap bundaran tersebut terdapat patung besar yang menjadi ciri khas Citra Raya sebagai kota seni.

Aksesibilitas menuju ke Citra Raya sangat baik karena dekat dengan 3 exit Tol Jakarta-Tangerang, yaitu exit Bitung, exit Cikupa, dan exit Balaraja Timur. Ketiga exit tol ini terhubungan dengan Jalan Raya Serang yang merupakan akses jalan utama menuju ke Citra Raya yang akan melewati gerbang utamanya. Lalu ke depannya terdapat tambahan 1 alternatif akses lagi, yaitu exit Tol Serpong-Balaraja (Serbaraja) yang berada persis di ujung selatan Citra Raya. Rencananya exit tol ini dapat digunakan pada tahun 2024.

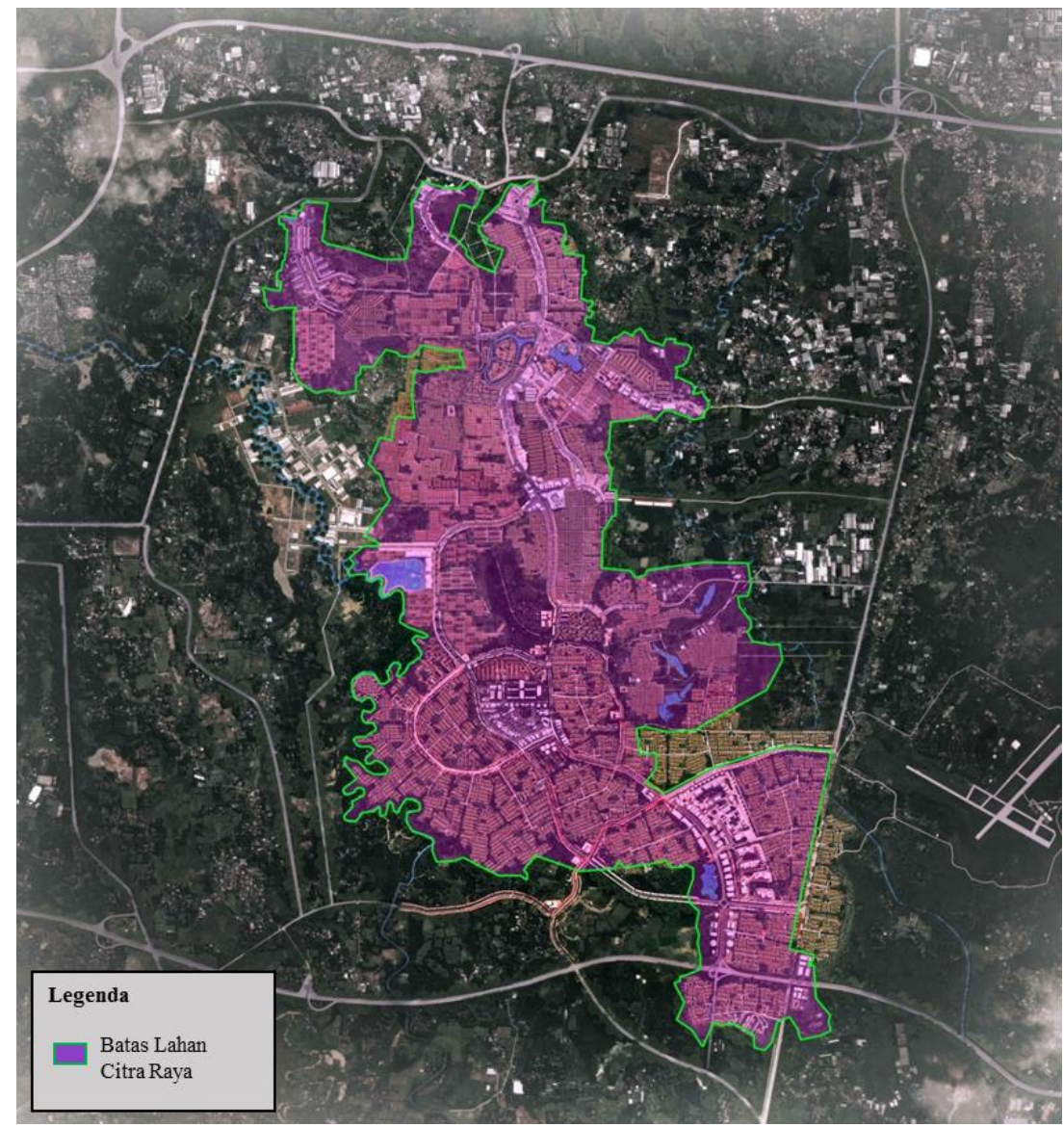

Gambar 2. Masterplan Citra Raya

Sumber: Manajemen Citra Raya, 2019 


\section{Data Hunian}

Citra Raya telah mengembangkan 51 cluster sampai dengan saat ini, 49 cluster di antaranya telah dihuni dan 2 cluster lainnya sedang dalam tahap pemasaran dan pembangunan, yaitu Lugano Lake Park (Certara Park dan Carona Park) dan The Trees (Pine Tree). Hunian yang dibangun sebagian besar merupakan hunian tapak, sedangkan untuk hunian vertikal saat ini hanya ada satu produk apartemen, yaitu EcoHome.

Tabel 1. Daftar Cluster Perumahan di Citra Raya

\begin{tabular}{lll}
\hline $\begin{array}{l}\text { Perumahan } \\
\text { Kelas Bawah }\end{array}$ & $\begin{array}{l}\text { Perumahan } \\
\text { Kelas Menengah }\end{array}$ & $\begin{array}{l}\text { Perumahan } \\
\text { Kelas Atas }\end{array}$ \\
\hline Serdang Asri 1, 2, 3 & Taman Puspa & Kusuma Dwipa \\
\hline Mekar Asri 1 dan 2 & Taman Puspita & Water Point \\
\hline Mulya Asri 1 dan 2 & Taman Palma & Park View \\
\hline Graha Pratama & Taman Raya & Lagoon Ville \\
\hline Graha Indira & Taman Picasso & The Leaf \\
\hline Graha Lestari & Taman Rembrant & Bali Dwipa \\
\hline Graha Pesona & Taman Caribbean & Belle Fleur \\
\hline Graha Segovia & Pesona Atlantis & Aurora \\
\hline Graha Sevilla & Taman Telaga & Fresco \\
\hline Graha Gardenia & Blossom Ville & Garden Ville \\
\hline Graha Raflesia & Melia Residence & Eco Residence \\
\hline Graha Catania & Taman Chrysant & The Trees (Pine Tree) \\
\hline Grand Catania & Lavender Lane & \\
\hline Graha Siena 1 dan 2 & Green Vista & \\
\hline Green Sevilla & Villa Verde & \\
\hline Green Savana & Florence & \\
\hline Beryl & Garden Grove & \\
\hline Tourmaline & Villagio & \\
\hline Chalcedony & Lugano Lake Park (Certara & \\
\hline Jade & Park dan Carona Park) & \\
\hline Sber: & & \\
\hline
\end{tabular}

Sumber: Manajemen Citra Raya, 2019

Perumahan yang ditawarkan sangat bervariasi, baik itu tipe rumah maupun harga jualnya. Tipe rumah paling kecil memiliki luas tanah $54 \mathrm{~m}^{2}$ dan tipe yang paling besar yaitu $450 \mathrm{~m}^{2}$, untuk ukuran bangunannya bervariasi karena banyak rumah yang telah direnovasi oleh pemilik rumahnya sendiri. Lalu untuk harga rumah yang ditawarkan mulai dari 200 juta rupiah sampai dengan 3,5 miliar rupiah. Tingkat hunian (occupancy rate) dari tiap cluster perumahan berbedabeda mulai dari $12 \%$ sampai $95 \%$. Cluster perumahan yang baru dibangun umumnya memiliki tingkat hunian yang masih rendah, sedangkan cluster perumahan yang sudah cukup lama dibangun memiliki tingkat hunian yang lebih tinggi, yaitu sekitar $70 \%-95 \%$

Tabel 2. Data Hunian di Citra Raya

\begin{tabular}{lllll}
\hline \multirow{2}{*}{ Jenis Hunian } & Segmentasi & Jumlah & $\begin{array}{l}\text { Jumlah Unit } \\
\text { Terbangun }\end{array}$ & $\begin{array}{l}\text { Jumlah Unit } \\
\text { Terhuni }\end{array}$ \\
\hline \multirow{2}{*}{ Hunian Tapak } & Kelas Atas & 20 Cluster & 2.176 & 1.270 \\
\cline { 2 - 5 } & Kelas Menengah & 19 Cluster & 6.380 & 4.285 \\
\hline
\end{tabular}




\begin{tabular}{lllll}
\hline Jenis Hunian & Segmentasi & Jumlah & $\begin{array}{l}\text { Jumlah Unit } \\
\text { Terbangun }\end{array}$ & $\begin{array}{l}\text { Jumlah Unit } \\
\text { Terhuni }\end{array}$ \\
\hline & Kelas Bawah & 12 Cluster & 14.297 & 11.475 \\
\hline Hunian Vertikal & Kelas Menengah & 2 Tower & 500 & 100 \\
\hline Total & & & 23.353 & 17.030 \\
\hline
\end{tabular}

Sumber: Hasil Olahan Penulis, 2020

\section{Analisis Perkembangan Citra Raya}

Perkembangan Citra Raya dapat dikelompokkan ke dalam tiga periode. Pada periode 1 (19942003), Ciputra Group berfokus pada pembangunan hunian kelas menengah ke bawah serta penyediaan fasilitas dasar kota. Hunian kelas bawah yang dibangun sebagian besar merupakan rumah BTN (Bank Tabungan Negara), yaitu Serdang Asri, Mekar Asri, dan Mulya Asri. Penamaan cluster pada periode ini memiliki ciri khas, yaitu menggunakan nama "taman" dan "graha". Perumahan kelas menengah menggunakan nama "taman", sedangkan nama "graha" untuk perumahan kelas bawah. Selain itu, penamaan jalan di dalam cluster juga unik karena berkaitan dengan musik, seperti Jalan Cello, Jalan Dawai, Jalan Flute, Jalan Harpa, Jalan Irama, dan Jalan Kolintang.

Berbagai jenis fasilitas telah dibangun pada periode ini, mulai dari fasilitas pendidikan, peribadatan, kesehatan, komersial, dan olahraga. Ciputra Group belum terlalu berfokus pada pembangunan komersial skala besar sehingga fasilitas komersial yang dibangun masih berupa ruko saja untuk memenuhi kebutuhan sehari-hari penghuni Citra Raya.

Lalu dalam periode 2 (2004-2012), perumahan yang dibangun sebagian besar masih untuk kelas menengah dan bawah. Konsep perumahan juga masih sama yaitu berupa cluster, namun untuk penamaan cluster dan jalan di dalamnya mulai menggunakan istilah asing. Fasilitas yang dibangun pada periode ini semakin beragam dan memiliki skala pelayanan yang lebih luas, seperti Ciputra Hospital, World of Wonder, dan Water World. Pada periode sebelumnya Ciputra Group hanya membangun ruko sebagai fasilitas komersial, namun di periode ini dibangun juga pasar modern, pusat otomotif, dan pusat makanan (food court).

Selain menyediakan berbagai fasilitas di atas, Ciputra Group juga mengembangkan area unggulan atau central business district (CBD) yang akan menjadi pusat bisnis dan investasi baru di Citra Raya. Ada dua CBD yang dikembangkan pada periode ini, yaitu CBD pertama yang berada di area bundaran 1 dan CBD kedua yang berada di area bundaran 3.

Selanjutnya pada periode 3 (2013-2019), Ciputra Group banyak membangun perumahan kelas atas serta fasilitas berskala besar. Jika pada dua periode sebelumnya konsep perumahan berupa cluster, pada periode ini konsepnya menjadi mega cluster dimana di dalamnya terdiri dari beberapa cluster kecil dan fasilitas pelengkap lainnya. Terdapat empat mega cluster yang dikembangkan, yaitu Ecopolis, Garden Ville, Villagio, dan Lugano Lake Park. Konsep ini memiliki beberapa keuntungan, salah satunya adalah perumahan dan fasilitas di dalamnya dapat terintegrasi dengan lebih baik. Selain itu, pengembang juga dapat menghemat pembangunan fasilitas, misalnya satu unit club house dapat digunakan oleh semua penghuni di dalam mega cluster tersebut. Hal ini dapat dilihat pada pengembangan Ecopolis dan Garden Ville. Pada periode ini Ciputra Group banyak mengembangkan fasilitas komesial untuk menunjang kebutuhan penghuni serta kegiatan bisnis di Citra Raya.

Setelah sukses mengembangkan dua CBD sebelumnya, pada periode 3 ini Ciputra Group mengembangkan CBD ketiga Citra Raya yang fokus utamanya adalah pembangunan pusat perbelanjaan. Hal ini dimaksudkan untuk menjadi pemicu pembangunan fasilitas lain di 
sekitarnya. Pembangunan fasilitas seperti CBD diperkirakan akan menjadi destinasi bisnis dan investasi baru sekaligus mendorong peningkatan harga tanah di Citra Raya. Pembangunan CBD ketiga sudah dimulai saat groundbreaking pembangunan Mall Ciputra pada Oktober 2017 yang lalu.

Pengembangan Citra Raya ke depannya akan mengarah ke selatan dan semakin dekat dengan rencana Jalan Tol Serbaraja (Serpong - Balaraja). Jalan tol sepanjang 38 kilometer ini rencananya akan mulai beroperasi pada tahun 2024. Lokasinya berada tepat di ujung selatan Citra Raya dan akan terdapat satu exit tol di sana. Hal ini menjadi peluang baik untuk menaikkan nilai investasi di Citra Raya, semakin ke arah selatan berarti semakin dekat dengan Jakarta sehingga nilai investasi juga akan semakin tinggi.

\section{Analisis Perkembangan Perumahan}

Dalam setiap periode pengembangan Citra Raya, Ciputra Group membangun semua segmentasi/ kelas perumahan, baik itu perumahan kelas bawah, perumahan kelas menengah, maupun perumahan kelas atas. Namun, dalam setiap periode tersebut komposisi kelas perumahannya berbeda-beda. Perumahan yang dibangun Ciputra Group ada dua jenis, yaitu hunian tapak dan hunian vertikal.

Tabel 3. Jumlah Perumahan Berdasarkan Periode Pembangunan dan Segmentasi

\begin{tabular}{lllll}
\hline Segmentasi & $\begin{array}{l}\text { Periode } \mathbf{1} \\
\mathbf{( 1 9 9 4 - 2 0 0 3 )}\end{array}$ & $\begin{array}{l}\text { Periode 2 } \\
\mathbf{( 2 0 0 4 - 2 0 1 2 )}\end{array}$ & $\begin{array}{l}\text { Periode 3 } \\
\mathbf{( 2 0 1 3 - 2 0 1 9 )}\end{array}$ & Total \\
\hline Kelas Atas & 48 & 602 & 1.526 & 2.176 \\
\hline Kelas Menengah & 2.675 & 1.784 & 2.421 & 6.880 \\
\hline Kelas Bawah & 7.460 & 5.602 & 1.235 & 14.297 \\
\hline Total & 10.183 & 7.988 & 5.182 & 23.353 \\
\hline
\end{tabular}

Sumber: Hasil Olahan Penulis, 2019

Meskipun jumlah hunian kelas atas yang dibangun terus meningkat, sedangkan jumlah hunian kelas bawah terus menurun, komposisi hunian yang ada di Citra Raya saat ini sudah sesuai dengan ketentuan / aturan dari pemerintah. Hal ini dikarenakan Ciputra Group telah banyak membangun hunian kelas bawah dan menengah pada periode 1 dan 2 , sedangkan perumahan kelas atas baru mulai banyak dibangun pada periode 3 .

Tabel 4. Persentase Kelas Perumahan yang Dibangun per Periode

\begin{tabular}{lllll}
\hline Periode & Hunian Kelas Bawah & Hunian Kelas Menengah & Hunian Kelas Atas & Total \\
\hline 1 & $73,26 \%$ & $26,27 \%$ & $0,47 \%$ & $100 \%$ \\
\hline 2 & $70,13 \%$ & $22,33 \%$ & $7,54 \%$ & $100 \%$ \\
\hline 3 & $23,83 \%$ & $46,72 \%$ & $29,45 \%$ & $100 \%$ \\
\hline Total Hunian & $61,22 \%$ & $29,46 \%$ & $9,32 \%$ & $100 \%$ \\
\hline
\end{tabular}

Sumber: Hasil Olahan Penulis, 2019

Berdasarkan tabel di atas dapat diketahui bahwa komposisi perumahan di Citra Raya saat ini adalah 9,32\% hunian kelas atas, 29,46\% hunian kelas menengah, dan 61,22\% hunian kelas bawah. Ciputra Group sepertinya masih mengikuti kebijakan hunian berimbang yang lama, yaitu yang ditetapkan dalam Surat Keputusan Bersama (SKB) Menteri Dalam Negeri, Menteri Pekerjaan Umum, dan Menteri Negara Perumahan Rakyat Nomor 648-384 Tahun 1992, Nomor 739/KPTS/1992, dan Nomor 09/KPTS/1992 tentang Pedoman Pembangunan Perumahan dan Permukiman dengan Lingkungan Hunian Berimbang dimana komposisi antara rumah mewah, 
rumah menengah, dan rumah sederhana adalah $1: 3: 6$ atau $10 \%$ : 30\% : 60\%. Jika dibandingkan dengan aturan ini, maka komposisi hunian yang ada di Citra Raya sudah sangat mendekati.

Kebijakan mengenai hunian berimbang yang saat ini berlaku adalah berdasarkan Peraturan Menteri Perumahan Rakyat (Permenpera) Nomor 10 Tahun 2012 dengan perbandingan antara rumah mewah, rumah menengah, dan rumah sederhana adalah $1: 2: 3$ atau $16,67 \%: 33,33 \%$ : $50 \%$. Jika mengacu pada aturan ini, maka Ciputra Group dapat membangun 2.590 unit hunian kelas atas dan 2.651 unit hunian kelas menengah tanpa harus membangun hunian kelas bawah lagi dalam beberapa waktu ke depan.

\section{Analisis Penyediaan Fasilitas}

Semakin lengkap fasilitas di dalam suatu kota maka akan menjadi nilai tambah dan daya tarik tersendiri bagi orang untuk tinggal di kota tersebut. Properti yang berlokasi di pusat kota dan dekat dengan fasilitas-fasilitas, seperti sekolah, rumah sakit, pusat perbelanjaan, transportasi umum, dan akses jalan yang baik tentu memiliki harga jual yang jauh lebih tinggi dibandingkan dengan properti yang berada jauh dari fasilitas-fasilitas tersebut di atas.

Tabel 5. Perkembangan Jumlah Fasilitas di Citra Raya Berdasarkan Skala Pelayanan

\begin{tabular}{lllll}
\hline Skala Pelayanan & $\begin{array}{l}\text { Periode } \mathbf{1} \\
(\mathbf{1 9 9 4}-\mathbf{2 0 0 3 )}\end{array}$ & $\begin{array}{l}\text { Periode } \mathbf{2} \\
(\mathbf{2 0 0 4}-\mathbf{2 0 1 2})\end{array}$ & $\begin{array}{l}\text { Periode 3 } \\
(\mathbf{2 0 1 3}-\mathbf{2 0 1 9 )}\end{array}$ & Total \\
\hline Neighborhood & 22 & 27 & 23 & 72 \\
\hline Community & 5 & 17 & 6 & 28 \\
\hline Regional & 1 & 4 & 5 & 10 \\
\hline Super Regional & 0 & 0 & 0 & 0 \\
\hline Internasional & 0 & 0 & 0 & 0 \\
\hline Total & 28 & 48 & 34 & 110 \\
\hline
\end{tabular}

Sumber:Hasil Olahan Penulis, 2019

Fasilitas terdapat di Citra Raya dapat dikelompokkan menjadi lima jenis berdasarkan skala pelayanannya, yaitu neighborhood, community, regional, super regional, dan internasional.

a. Fasilitas tipe neighborhood memiliki skala pelayanan untuk tingkat lingkungan perumahan atau kelurahan, meliputi KB, TK, SD, masjid, ruko, dan club house. Terdapat 72 fasilitas di Citra Raya yang termasuk tipe ini yang terdiri dari 10 sekolah, 29 masjid, 29 kompleks ruko, dan 4 club house.

b. Fasilitas tipe community memiliki skala pelayanan untuk tingkat kecamatan, meliputi SMP, SMA, gereja, vihara, kelenteng, ritel skala community, taman kota, sport club, dan bioskop. Terdapat 28 fasilitas di Citra Raya yang termasuk ke dalam tipe ini yang terdiri dari 12 sekolah, 2 gereja, 2 vihara, 1 kelenteng, 8 ritel skala community, 1 taman kota, 1 sport club, dan 1 bioskop. Ritel atau fasilitas komersial dengan tipe community adalah Pasar Modern City Market, Citra Auto Center, Bursa Mobil Citra, Ciffest, EcoPlaza, Citra Raya Square 1 dan 2, serta MardiGras.

c. Fasilitas tipe regional memiliki skala pelayanan untuk tingkat kota/kabupaten, yang terdiri dari perguruan tinggi/universitas, rumah sakit, ritel skala regional, theme park, dan water park. Citra Raya memiliki 10 fasilitas tipe regional, yaitu 4 perguruan tinggi, 1 rumah sakit, 1 mal, office park, gudang (3-in-1 building), theme park, dan water park.

d. Fasilitas tipe super regional memiliki skala pelayanan untuk tingkat antar kota atau provinsi. Saat ini belum ada fasilitas tipe ini di Citra Raya.

e. Fasilitas tipe internasional memiliki skala pelayanan untuk tingkat nasional bahkan sampai internasional. Saat ini Citra Raya juga belum memiliki fasilitas tipe ini. 
Dapat dilihat bahwa fasilitas yang dibangun di Citra Raya semakin lama semakin berkembang dari segi skala pelayanannya. Meskipun jumlah fasilitas yang dibangun untuk tipe neighborhood dan community berkurang, namun fasilitas tipe regional terus bertambah jumlahnya. Melihat perkembangan Citra Raya yang pesat, ke depannya mungkin saja fasilitas yang dibangun di Citra Raya dapat mencapai skala super regional bahkan hingga internasional.

Tabel 6. Pembangunan Fasilitas di Citra Raya per Periode

\begin{tabular}{|c|c|c|c|}
\hline Jenis Fasilitas & $\begin{array}{l}\text { Periode } 1 \\
(1994-2003)\end{array}$ & $\begin{array}{l}\text { Periode } 2 \\
(2004-2012)\end{array}$ & $\begin{array}{l}\text { Periode } 3 \\
(2013-2019)\end{array}$ \\
\hline Pendidikan & $\begin{array}{l}\text { Terdapat } 3 \text { KB, } 3 \text { TK, } 6 \\
\text { SD, } 3 \text { SMP, } 2 \text { SMA, } 1 \\
\text { SMK, dan } 1 \text { Sekolah } \\
\text { Tinggi }\end{array}$ & $\begin{array}{l}\text { Dibangun } 3 \text { KB, } 3 \text { TK, } 6 \\
\text { SD, } 5 \text { SMP, } 1 \text { SMA, } 1 \\
\text { SMK, dan } 1 \text { Sekolah } \\
\text { Tinggi }\end{array}$ & $\begin{array}{l}\text { Dibangun } 1 \text { KB, } 2 \text { TK, } 5 \\
\text { SD, } 3 \text { SMP, } 1 \text { SMA, } 2 \\
\text { SMK, dan } 2 \text { Universitas }\end{array}$ \\
\hline Peribadatan & $\begin{array}{l}\text { Terdapat } 11 \text { masjid } \\
\text { dan } 1 \text { vihara }\end{array}$ & $\begin{array}{l}\text { Dibangun } 15 \text { masjid, } 1 \\
\text { vihara, dan } 2 \text { gereja }\end{array}$ & $\begin{array}{l}\text { Dibangun } 3 \text { masjid dan } \\
1 \text { kelenteng }\end{array}$ \\
\hline Kesehatan & - & $\begin{array}{l}\text { Dibangun } 1 \text { rumah } \\
\text { sakit }\end{array}$ & - \\
\hline Komersial & $\begin{array}{l}\text { Dibangun } 6 \text { kompleks } \\
\text { ruko }\end{array}$ & $\begin{array}{l}\text { Dibangun } 8 \text { kompleks } \\
\text { ruko dan } 6 \text { pusat } \\
\text { perbelanjaan }\end{array}$ & $\begin{array}{l}\text { Dibangun } 15 \text { kompleks } \\
\text { ruko dan } 3 \text { pusat } \\
\text { perbelanjaan }\end{array}$ \\
\hline Rekreasi / Olahraga & Dibangun 1 sport club & $\begin{array}{l}\text { Dibangun } 2 \text { club house, } \\
1 \text { theme park, dan } 1 \\
\text { water park }\end{array}$ & $\begin{array}{l}\text { Dibangun } 2 \text { club house, } \\
1 \text { taman kota, dan } 1 \\
\text { bioskop }\end{array}$ \\
\hline
\end{tabular}

Sumber: Hasil Olahan Penulis, 2019

Dapat disimpulkan bahwa fasilitas yang dibangun di Citra Raya sangat beragam dalam rangka memenuhi kebutuhan penghuni di dalam Citra Raya serta masyarakat yang tinggal di sekitarnya. Citra Raya memiliki penghuni yang terdiri dari beragam latar belakang, oleh karena itu kebutuhan dan keinginan setiap orang dapat berbeda-beda dalam memilih suatu fasilitas. Dengan membangun fasilitas yang semakin beragam, maka diharapkan kebutuhan dari setiap penghuni dapat terpenuhi.

\section{Analisis Ketercukupan Fasilitas}

Perhitungan kebutuhan fasilitas di Citra Raya menggunakan dua acuan/standar dari pemerintah, yaitu SNI 03-1733-2004 dan Perda DKI Jakarta No.6 Tahun 1999. Acuan berdasarkan SNI 031733-2004 berlaku untuk seluruh daerah yang ada di Indonesia, baik itu kota besar maupun kota kecil dianggap sama. Kabupaten Tangerang sendiri tidak memiliki standar kebutuhan fasilitas, oleh karena itu menggunakan standar kebutuhan fasilitas DKI Jakarta. Citra Raya memiliki karakteristik yang sama dengan DKI Jakarta, yaitu merupakan kota besar. Selain itu, Citra Raya juga merupakan kota satelit dari Jakarta sehingga kebutuhannya dianggap sama dengan DKI Jakarta. 
Tabel 7. Hasil Analisis Kebutuhan Fasilitas di Citra Raya

\begin{tabular}{|c|c|c|c|c|c|}
\hline \multirow{2}{*}{ Jenis Fasilitas } & & \multicolumn{2}{|c|}{ SNI 03-1733-2004 } & \multicolumn{2}{|c|}{$\begin{array}{l}\text { Perda DKI Jakarta No.6 } \\
\text { Tahun } 1999\end{array}$} \\
\hline & & $\begin{array}{l}\text { Kebutuhan } \\
\text { Jumlah }\end{array}$ & $\begin{array}{l}\text { Kebutuhan } \\
\text { Luas }\end{array}$ & $\begin{array}{l}\text { Kebutuhan } \\
\text { Jumlah }\end{array}$ & $\begin{array}{l}\text { Kebutuhan } \\
\text { Luas }\end{array}$ \\
\hline \multirow{6}{*}{ Pendidikan } & KB & - & - & - & - \\
\hline & TK & $x$ & - & $x$ & - \\
\hline & SD & $x$ & - & $x$ & - \\
\hline & SMP & $x$ & - & $\mathrm{V}$ & - \\
\hline & SMA/SMK & $x$ & - & V & - \\
\hline & Perguruan Tinggi & - & - & V & - \\
\hline \multirow{6}{*}{ Peribadatan } & Masjid & V & V & V & V \\
\hline & Gereja Katolik & - & - & V & V \\
\hline & Gereja Kristen & - & - & $\mathrm{V}$ & $\mathrm{V}$ \\
\hline & Kelenteng & - & - & V & $\mathrm{V}$ \\
\hline & Vihara & - & - & V & V \\
\hline & Pura & $x$ & $x$ & $x$ & $x$ \\
\hline Kesehatan & Rumah Sakit & - & - & $\mathrm{V}$ & V \\
\hline \multirow{2}{*}{$\begin{array}{l}\text { Perdagangan / } \\
\text { Komersial }\end{array}$} & $\begin{array}{l}\text { Pertokoan / } \\
\text { Pasar } \\
\text { Lingkungan }\end{array}$ & V & V & V & V \\
\hline & $\begin{array}{l}\text { Pusat } \\
\text { Perbelanjaan }\end{array}$ & V & V & V & V \\
\hline \multirow{3}{*}{$\begin{array}{l}\text { Rekreasi / } \\
\text { Olahraga }\end{array}$} & $\begin{array}{l}\text { Taman } \\
\text { Lingkungan }\end{array}$ & $x$ & $\mathrm{~V}$ & $x$ & V \\
\hline & $\begin{array}{l}\text { Lapangan } \\
\text { Olahraga }\end{array}$ & V & $\mathrm{V}$ & V & V \\
\hline & Kolam Renang & - & - & V & V \\
\hline
\end{tabular}

*Ket: V (Memenuhi Standar), X (Tidak Memenuhi Standar), - (Tidak Dapat Dihitung)

Sumber: Hasil Olahan Penulis, 2020

Fasilitas yang ada di Citra Raya sangat beragam, sedangkan di dalam standar yang ada beberapa jenis fasilitas tersebut tidak memiliki standar kebutuhan. Oleh karena itu, beberapa jenis fasilitas tidak dapat dihitung standar kebutuhannya. Secara garis besar, beberapa fasilitas masih belum memenuhi standar jika dilihat dari jumlah yang terbangun, terutama fasilitas pendidikan berupa TK dan SD. Hal ini dikarenakan fasilitas TK dan SD yang didata oleh penulis hanyalah TK dan SD yang cukup besar. Sebenarnya terdapat beberapa TK dan SD yang menempati beberapa unit rumah tinggal di dalam cluster-cluster perumahan, namun sekolah tersebut tidak didata. Lalu jika dilihat dari luas fasilitas yang telah terbangun, fasilitas-fasilitas tersebut semuanya telah memenuhi standar kebutuhan yang ada. Semua perhitungan kebutuhan fasilitas di atas menggunakan asumsi jumlah penduduk sebesar 68.021 jiwa.

\section{Analisis Hubungan Perumahan dan Fasilitas}

Dalam dua analisis sebelumnya telah dibahas bahwa jumlah perumahan dan fasilitas di Citra Raya terus bertambah setiap periodenya. Pada analisis ini, akan dilihat hubungan antara perkembangan perumahan dan penyediaan fasilitas tersebut dengan melakukan uji korelasi. 
Tabel 8. Jumlah Hunian dan Fasilitas Terbangun per Tahun

\begin{tabular}{|c|c|c|c|c|c|c|c|c|}
\hline \multirow{2}{*}{$\begin{array}{l}\text { Tahun } \\
\text { Bangun }\end{array}$} & \multicolumn{3}{|c|}{ Jumlah Hunian } & \multicolumn{5}{|c|}{ Jumlah Fasilitas } \\
\hline & $\begin{array}{l}\text { Kelas } \\
\text { Bawah }\end{array}$ & $\begin{array}{l}\text { Kelas } \\
\text { Menengah }\end{array}$ & $\begin{array}{l}\text { Kelas } \\
\text { Atas }\end{array}$ & $\begin{array}{l}\text { Neigh- } \\
\text { borhood }\end{array}$ & $\begin{array}{l}\text { Commu- } \\
\text { nity }\end{array}$ & Regional & $\begin{array}{l}\text { Super } \\
\text { Regional }\end{array}$ & $\begin{array}{l}\text { Inter- } \\
\text { nasional }\end{array}$ \\
\hline$<2001$ & 5.945 & 2.362 & 48 & 17 & 1 & 0 & 0 & 0 \\
\hline 2001-2004 & 9.641 & 3.411 & 48 & 23 & 10 & 1 & 0 & 0 \\
\hline 2005-2009 & 13.062 & 4.105 & 230 & 44 & 18 & 3 & 0 & 0 \\
\hline 2010 & 13.062 & 4.459 & 650 & 45 & 20 & 5 & 0 & 0 \\
\hline 2011 & 13.062 & 4.459 & 650 & 49 & 21 & 5 & 0 & 0 \\
\hline 2012 & 13.062 & 4.459 & 855 & 53 & 22 & 5 & 0 & 0 \\
\hline 2013 & 13.062 & 4.793 & 1.113 & 55 & 24 & 7 & 0 & 0 \\
\hline 2014 & 13.062 & 4.793 & 1.113 & 60 & 25 & 8 & 0 & 0 \\
\hline 2015 & 13.062 & 4.793 & 1.417 & 66 & 28 & 8 & 0 & 0 \\
\hline 2016 & 13.828 & 4.793 & 1.737 & 66 & 28 & 8 & 0 & 0 \\
\hline 2017 & 14.297 & 5.798 & 1.883 & 67 & 28 & 9 & 0 & 0 \\
\hline 2018 & 14.297 & 6.335 & 1.883 & 69 & 28 & 9 & 0 & 0 \\
\hline 2019 & 14.297 & 6.880 & 2.176 & 70 & 28 & 10 & 0 & 0 \\
\hline
\end{tabular}

Sumber: Hasil Olahan Penulis, 2020

Selanjutnya tabel di atas akan diolah menggunakan analisis korelasi, yaitu salah satu teknik pengolahan data statistik yang dapat digunakan untuk mencari hubungan antara dua variabel atau lebih secara kuantitatif. Nilai korelasi akan positif jika dua atau lebih variabel yang berkorelasi menunjukkan arah yang sama. Apabila variabel $X$ mengalami peningkatan maka variabel $Y$ juga akan meningkat. Sebaliknya, nilai korelasi akan negatif jika dua atau lebih variabel yang berkorelasi menunjukkan arah yang berlawanan. Apabila variabel $\mathrm{X}$ mengalami peningkatan, maka variabel $Y$ akan menurun.

Berikut adalah pedoman untuk memberikan interpretasi koefisien korelasi (Haese, 2012):

- $0,00 \leq r<0,10$ (tidak ada korelasi)

- $0,10 \leq r<0,50$ (korelasi rendah)

- $0,50 \leq r<0,87$ (korelasi sedang)

- $0,87 \leq r<0,95$ (korelasi kuat)

- $0,95 \leq r<1,00$ (korelasi sangat kuat)

- $r=1,00 \quad$ (korelasi sempurna)

Tabel 9. Hasil Analisis Korelasi antara Perkembangan Hunian dan Penyediaan Fasilitas di Citra Raya

\begin{tabular}{lcccccc}
\hline & $\begin{array}{c}\text { Hunian Kelas } \\
\text { Bawah }\end{array}$ & $\begin{array}{c}\text { Hunian Kelas } \\
\text { Menengah }\end{array}$ & $\begin{array}{c}\text { Hunian } \\
\text { Kelas } \\
\text { Atas }\end{array}$ & $\begin{array}{c}\text { Fasilitas Skala } \\
\text { Neighborhood }\end{array}$ & $\begin{array}{c}\text { Fasilitas Skala } \\
\text { Community }\end{array}$ & $\begin{array}{c}\text { Fasilitas } \\
\text { Skala } \\
\text { Regional }\end{array}$ \\
\hline $\begin{array}{l}\text { Hunian Kelas } \\
\text { Bawah }\end{array}$ & 1 & & & & & \\
\hline $\begin{array}{l}\text { Hunian Kelas } \\
\text { Menengah }\end{array}$ & 0,841847 & 1 & & & & \\
\hline $\begin{array}{l}\text { Hunian Kelas } \\
\text { Atas }\end{array}$ & 0,723077 & 0,906911 & 1 & 1 & 1 & \\
\hline $\begin{array}{l}\text { Fasilitas Skala } \\
\text { Neighborhood }\end{array}$ & 0,893828 & 0,893327 & 0,922271 & 0,947386 & 1 \\
\hline $\begin{array}{l}\text { Fasilitas Skala } \\
\text { Community }\end{array}$ & 0,946862 & 0,866959 & 0,860286 & 0,979548 & & \\
\hline $\begin{array}{l}\text { Fasilitas Skala } \\
\text { Regional }\end{array}$ & 0,836387 & 0,916525 & 0,955127 & 0,975457 & 0,94787 \\
\hline
\end{tabular}

Sumber: Hasil Olahan Penulis, 2020 
Hubungan antara hunian dengan fasilitas skala neighborhood, community, dan regional semuanya positif. Namun, ada yang hubungannya sedang, kuat, dan sangat kuat. Sedangkan hubungan antara hunian dengan fasilitas skala super regional dan internasional tidak dapat ditentukan karena saat ini Citra Raya belum memiliki fasilitas dengan kedua skala tersebut.

Fasilitas skala neighborhood memiliki hubungan yang kuat positif dengan semua kelas hunian karena fasilitas ini memiliki skala pelayanan terkecil sehingga perlu ada di dekat setiap perumahan. Contoh fasilitas ini seperti ruko, masjid, dan club house.

Lalu untuk fasilitas skala community memiliki hubungan yang sedang dan kuat positif dengan hunian. Namun, terlihat bahwa semakin tinggi kelas huniannya maka angka korelasinya semakin menurun. Hal ini disebabkan karena fasilitas skala community dalam 4 tahun terakhir belum dibangun lagi, sedangkan hunian kelas menengah dan kelas atas sedang banyak dibangun.

Berdasarkan tabel di atas, dapat dilihat pula bahwa fasilitas skala regional memiliki hubungan yang sangat kuat positif dengan hunian kelas atas. Hal ini disebabkan karena banyak fasilitas skala regional yang baru dibangun dalam kurun waktu 10 tahun terakhir, bersamaan dengan pembangunan kelas menengah dan kelas atas yang sedang banyak juga. Selain itu, untuk pembangunan fasilitas komersial berskala regional juga terkait dengan daya beli konsumen. Misalnya mal yang baru dibangun ketika jumlah hunian kelas menengah ke atas telah banyak terbangun karena target pasar dari mal adalah konsumen kelas menengah ke atas.

Dapat disimpulkan bahwa penambahan jumlah perumahan diikuti dengan penambahan jumlah fasilitas di sekitarnya. Hal ini juga sesuai dengan teori dari Yudohusodo, dimana disebutkan bahwa salah satu faktor yang mempengaruhi perkembangan perumahan adalah faktor sarana dan prasarana. Semakin lengkap suatu fasilitas kota, maka mampu menjadi daya tarik bagi orang untuk tinggal di kota tersebut.

\section{KESIMPULAN DAN SARAN Kesimpulan}

Citra Raya merupakan proyek kota mandiri terbesar Ciputra Group yang dikembangkan di atas lahan seluas $2.760 \mathrm{Ha}$. Saat ini Citra Raya telah memiliki 51 cluster perumahan dengan jumlah unit hunian yang terbangun sebanyak 23.353 unit dan yang terhuni sebanyak 17.030 unit. Hunian yang dibangun sebagian besar masih merupakan hunian tapak (landed house) karena masih banyak lahan kosong yang tersedia dan harga tanahnya yang belum terlalu tinggi. Sedangkan untuk hunian vertikal pasarnya belum sebaik hunian tapak, sehingga saat ini baru ada 2 tower apartemen setinggi 5 lantai yang dibangun pada tahun 2017 yang lalu. Dalam membangun perumahan, Ciputra Group terus memperhatikan komposisi perumahan yang ada. Pada periode awal pembangunan Citra Raya, jumlah hunian kelas atas yang dibangun sangat sedikit. Namun seiring dengan berkembangnya Citra Raya, jumlah hunian kelas atas yang dibangun juga semakin banyak. Saat ini komposisi hunian di Citra Raya telah sesuai dengan pola hunian berimbang, yaitu 1:3:6.

Ciputra Group terus menghadirkan fasilitas-fasilitas terbaru di Citra Raya. Fasilitas yang ada mulai dari skala neighborhood sampai dengan skala regional. Fasilitas yang dibangun pada periode awal berupa fasilitas-fasilitas dasar yang memiliki skala pelayanan yang kecil, lalu secara bertahap fasilitas yang dibangun semakin bertambah skala pelayanannya. Pengguna dari fasilitas itu bukan hanya penghuni Citra Raya saja, tetapi juga masyarakat yang tinggal di sekitarnya. Dilihat dari ketercukupannya, fasilitas yang ada di Citra Raya telah mencukupi kebutuhan penghuni di dalamnya. Meskipun beberapa fasilitas masih kurang dari segi 
jumlahnya, namun dari segi luasan fasilitas yang terbangun telah memenuhi standar yang ada. Keberadaan berbagai fasilitas di sekitar Citra Raya yang cukup beragam juga semakin melengkapi kebutuhan dari penghuni.

Perkembangan hunian dan penyediaan fasilitas di Citra Raya memiliki hubungan yang sedang sampai sangat kuat positif. Bertambahnya jumlah hunian diikuti dengan bertambahnya jumlah fasilitas. Perkembangan hunian kelas menengah ke atas juga mempunyai pengaruh terhadap pembangunan beberapa jenis fasilitas. Hal ini dapat terlihat pada pembangunan fasilitas komersial, seperti mal. Cepat atau lambatnya suatu kota untuk berkembang bukan hanya disebabkan oleh fasilitas yang tersedia di dalamnya, tetapi ada faktor-faktor lainnya yang tidak diteliti dalam penelitian ini.

\section{Saran}

Setelah melakukan penelitian ini, penulis memberikan beberapa saran untuk penelitian lebih lanjut. Pertama, penelitian berikutnya dapat mempertimbangkan preferensi penghuni sebagai salah satu variabel untuk mengetahui kebutuhan dan ketercukupan fasilitas. Preferensi penghuni sebenarnya memiliki peran yang cukup penting dalam penyediaan fasilitas karena belum tentu semua penghuni menggunakan fasilitas yang ada di dalam Citra Raya. Kedua, hunian dan fasilitas yang berada di sekitar Citra Raya juga dapat diperhatikan di dalam penelitian selanjutnya karena penggunaan fasilitas bersifat borderless. Ketiga, agar penelitian selanjutnya dapat lebih baik juga dapat menambahkan standar-standar lainnya dalam melakukan perhitungan kebutuhan fasilitas. Apabila ada standar penyediaan fasilitas dari developer maka hasilnya dapat jauh lebih baik.

\section{REFERENSI}

Batudoka, Z. (2005, Februari). Kota Baru dan Aspek Perumahan Mendepan. Jurnal SMARTek, Vol. 3, No. 1, hal. 27-36.

Ciputra Group. Citra Raya (Official Website). Diambil kembali dari https://citraraya.com (18 Maret 2020)

Haese, R., Haese, S., Haese, M., Mäenpää, M., \& Humphries, M. (2012). Mathematics for the International Student. Australia: Haese Mathematics.

Kuswartojo, T. (2010). Mengusik Tata Penyelenggaraan Lingkungan Hidup dan Pemukiman. Bandung: Kelompok Keahlian Perumahan dan Permukiman ITB.

Oentarto, S., I. M., \& Riyadmadji, D. (2004). Menggagas Format Otonomi Daerah Masa Depan. Jakarta: Samitra Media Utama.

Perloff, H. S., \& Sandberg, N. C. (1973). New Towns: Why and For Whom. New York, Washington, dan London: Pall Mall Press.

Sujarto, D. (1993, September). Perkembangan Kota Baru. Jurnal PWK FTSP-ITB Nomor 9, hal. 324.

Syelvi. (2018). Studi Hubungan Penyediaan Fasilitas Kota Terhadap Perkembangan Penyediaan Perumahan di Kota Baru (Studi Kasus: BSD). Jakarta: Program Studi Perencanaan Kota Konsentrasi Real Estate Universitas Tarumanagara.

Yudohusodo, S. (1991). Rumah Untuk Seluruh Rakyat. Jakarta: INKOPPOL. 